\title{
Accounting Issues: An Essay Series Part IV-Property, Plant, \& Equipment
}

Judy Laux, (E-mail: jlaux@ coloradocollege.edu), Colorado College

\begin{abstract}
This fourth article in a series of theoretical essays intended to supplement the introductory financial accounting course is dedicated to the topic of property, plant, and equipment (PP\&E), including both the accounting treatment and its related conceptual connections. The paper also addresses the measurement dilemmas, scandalous accounting episodes that have made the headlines, and both theoretical and empirical studies about PP\&E that might be of interest to both students and professors.
\end{abstract}

\section{INTRODUCTION}

f you have just joined this series, Laux [2007(a)] outlines the need for a theory-based introduction to the major accounting elements, providing a mountain-hiking analogy context within which we are discussing daily accounting dilemmas (the initial steps taken at the base of the mountain) and the adjusting process (in the foothills of the journey), with the ultimate goal of reflecting economic reality in the financial statements (at the peak of the mountain). "The Conceptual Framework at a Glance" section of the abovereferenced work describes the hierarchy of accounting characteristics (displayed once more on the following page) as it relates to the mountain hiking experience. For the students among you, you have no doubt learned the basic accounting associated with PP\&E, but the next section offers a brief overview of this material. After two sections addressing the related conceptual connections and measurement issues, the final portion of this article presents newsworthy examples of property-related scandals as well as some good articles for further investigation.

\section{ACCOUNTING FOR PROPERTY, PLANT, \& EQUIPMENT (IN BRIEF)}

Most introductory courses cover thoroughly the basic historical cost-based accounting for the acquisition and post-acquisition expenditures associated with depreciable property, plant, and equipment. The biggest difficulties in bringing PP\&E onto the books involve basket purchases, special one-time expenditures associated with the initial purchase, and interest related to self-constructed assets. The first of these "dilemmas" is handled on a proportionate basis based on the relative market values of land, buildings, and equipment (as the typical textbook example). This all makes relatively good sense, as we know this "basket" of assets probably can be bought at a market value below that of the individual assets, thus requiring the accountant to apportion the actual cost incurred based on some third-party assessment of relative market value. The conceptual importance of such treatment is addressed in the following section.

An additional problematic item involves those initial expenditures "necessarily and reasonably incurred to get the asset into its existing place and working condition"-items such as painting the company logo on the side of the truck, changing its tires (initially), or paying special permits to haul a new conveyor over public streets. If accountants mishandle such items (or make inappropriate journal entries), the journey to the peak (reflecting economic reality) is off to a bad start. We might be guilty of expensing items we reasonably should have "capitalized" (increasing a depreciable asset account). Finally, measuring (and appropriately accounting for) interest incurred during the construction of (self-made) assets presents both conceptual and measurement problems, as discussed in the next section. 


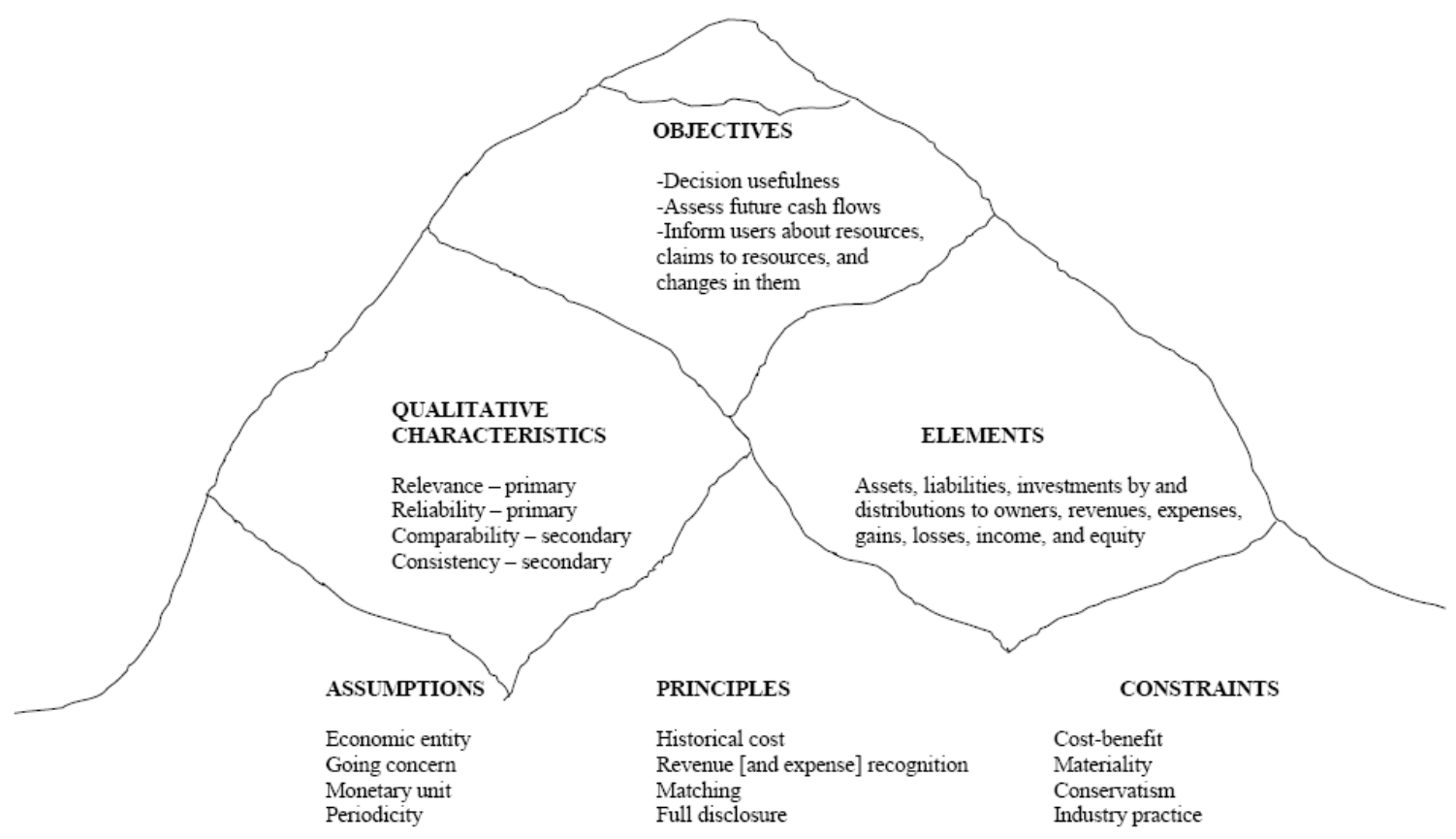

Post-acquisition expenditures (termed capital and revenue expenditures in the textbook) also pose special accounting challenges. Judgment is required to determine whether "investing" in an asset after it has been in use warrants debiting an asset or an expense account. You have no doubt discovered that post-acquisition expenditures, such as oil changes, that merely keep the asset functioning (and are generally considered in establishing such estimates as useful life and disposal value) are treated as "revenue" expenditures (debited to an expense account and "matched" against the revenues of the period), while expenditures associated with improving the asset or extending either its useful life or terminal value are generally to be capitalized (debited to an asset account, requiring a change in the remaining depreciable dollars and future annual depreciation charge).

Much of the introductory chapter on PP\&E is dedicated to the coverage of depreciation - the adjusting entry that allocates original cost (less any anticipated disposal value) to the periods benefited by the asset's use (estimated useful life). The mechanics are straightforward, and the result of annual depreciation is both an amount for depreciation expense on the income statement and a declining book value (original cost less accumulated depreciation) on the balance sheet. The following section speaks to some of the conceptual connections, including the choice among depreciation methods.

Revaluation of property, plant, or equipment when its value falls has occupied much of the accounting profession's time in recent years, and while the mechanics are generally relegated to the intermediate accounting stage, suffice it to say that the FASB requires downward revaluation on the balance sheet (and loss recognition on the income statement) through an adjusting entry when such value has fallen. It does not allow for recovery in the value, however, a conservative approach that will receive some attention in the following conceptual section. 
Finally, disposal of PP\&E can get quite complex when exchanges (rather than outright sales) are involved (an intermediate accounting topic), but generally the accounting steps for selling a depreciable asset are to remove the book value of the old asset, recognize the receipt (or payment) of cash, and balance the accounting entry with a gain (if a credit is required) or a loss (if a debit is required). The amount of the gain or loss can be determined (and envisioned) as the difference between book value and cash received or paid. If the cash is greater than book value, a gain results; a loss is recognized if cash received is less than this book value. This too has some interesting conceptual implications, as explained in a later section.

\section{THE CONCEPTUAL FRAMEWORK AND PP\&E}

As the mountain hiking illustration suggests, reaching the goal of decision usefulness at the mountaintop requires both relevance and reliability. Investors and creditors must find the reported property value influential to their assessment of past economic events or helpful in predicting future cash flows - that is, they deem the reported asset value to be relevant information. The value must also be reliably reported. The following paragraphs will elaborate on both aspects.

Though fixed assets are generally not intended for sale but rather for use in making future sales, sometimes creditors look to the value of these long-term assets as one indication of a company's ability to repay long-term loans. The amount of fixed assets plays a role in these lending decisions. Manufacturers, in particular, rely on a certain level of PP\&E to assure the continued sales that result in ultimate cash inflows to the firm, but judgments about a firm's profitability and return on investment are based in part on management's ability to limit the amount of investment in these non-interest-earning assets; fixed asset turnover (sales divided by fixed assets) helps in this determination. Finally, if property is not maintained and replaced in a timely fashion, this could signal future problems with product quality and demand, resulting in fewer expected future cash flows. However, the use of historical cost and book values based on this historical cost limit the relevance of the PP\&E value. The accounting profession has historically held the going concern concept as sufficient defense (stating that the assets are for use in the business and not for sale); thus the reliability of a known (objective and verifiable) historical cost takes precedence over the potential relevance associated with reporting current market values for these assets.

When firms make basket purchases and must allocate the historical cost to the various land, building, and equipment accounts, several theoretical constructs come into play. First, land is not depreciable, so the more dollars placed there, the fewer depreciation expense dollars will be recorded over the lives of the building and equipment. Should accountants over or undervalue the land, they will violate the matching principle. When apportioning the remaining original cost between the building and equipment accounts, different expected useful lives warrant some attention to appropriate allocation, again to honor the matching principle.

Two other property-related items also connect to the matching principle: Pre-use expenditures (such as painting the new delivery truck upon purchase or reinforcing the office floor for installation of a new copier) and post-acquisition expenditures (such as replacing a stairway with an escalator). Why do we care whether such things are capitalized or expensed as incurred? Because inappropriately expensing an item reduces this year's income and increases income for all future years of the asset's life, thus violating the matching concept. Capitalizing an item, such as a tune-up for a delivery truck already in use, overstates the current year's income (by holding the expenditure back from "Maintenance Expense") while understating future years' income (by recognizing artificially inflated "Depreciation Expense"). You can already see the temptation to smooth income by playing with the expense recognition aspect of these types of everyday events-leading us off the path to the mountaintop.

Companies must fully disclose their depreciation choices, and once a method is adopted, it must be used with consistency from year to year, though companies may be granted a change in method. Companies in financial distress have been known to take advantage of this "one-time" change to help sagging earnings. Long-lived assets with a relatively small cost, such as electric pencil sharpeners and waste paper baskets, are generally expensed in the period of purchase rather than depreciated as theoretically required based on both materiality and cost-benefit. Finally, selection of different depreciation methods can endanger comparability from company to company. 
Accountants must follow the relatively new asset impairment rule, requiring a judgment about whether the utility of a long-lived asset has been impaired, thus warranting loss recognition in the current period (to adhere to the matching concept). This determination is relevant, because it influences the assessment of future expected cash flows, but there is a trade-off, because the required judgment can hurt reliability. If the year's profitability is coming up short of expectations, managers are reluctant to recognize an impairment loss. Comparability might also be at issue if one firm acknowledges this asset reduction while another slips under the radar of its auditors. In addition, this conservatism based write-down (showing assets at the lower end of a defensible range of valuation) is a "one-way street," because the profession does not recognize recovery in value should it transpire, due to the conservatism constraint. The next section looks at some of the measurement issues related to property, plant, and equipment.

\section{MEASUREMENT ISSUES AND THEIR CONCEPTUAL CONNECTIONS}

Property, Plant, \& Equipment involves several measurement issues related to initial purchase, subsequent expenditures, periodic depreciation, and disposal. Of course, measurement problems typically have a resulting conceptual ramification. Each will be addressed in turn and the relevant items from the hierarchy applied.

One might think that the purchase of property, plant, and equipment represents a relatively straightforward part of accounting. Just take the amount from the bill of sale and debit the account. Of course, some fixed assets are not depreciable (land) while others are depreciable but at different rates (buildings, equipment, and land improvements, for example). Thus just making sure that the appropriate accounts are debited is an important first step in matching revenues and expenses as well as reflecting economic reality. Complicating factors for the purchase of land and buildings include real estate commissions, back taxes and assessments. For machinery and equipment, quite often the factory setting must be changed in advance to accommodate the item, and adjustments, fittings, down time, and material waste become problematic to estimate and capitalize. Finally, capitalization of interest incurred during self-construction offers the opportunity for additional headaches, both due to the need to select the appropriate interest rate and to estimate the borrowed amount. Again, careful measurement and classification are imperative to adhere to the matching principle, expense recognition, asset valuation, and comparability. If a company expenses interest that should have been capitalized, for example, the current year's income will be understated and income in all future years of the asset's useful life will be overstated (due to lower depreciation expense).

Expenditures incurred after purchase and use must be channeled into either expense accounts (for revenue expenditures) or the asset account (for betterments, life prolonging expenditures, or extraordinary repair events - all capital expenditures). Determining whether adding a new clutch to the delivery truck will extend its useful life or increase its salvage value is not always as clear-cut as one might expect; often the amount of the post-acquisition expenditure will dictate whether expensing or capitalizing is more appropriate based on materiality. Still, reflecting economic reality is at issue, and the distinction is an important one.

Some of the greatest measurement challenges relate to periodic depreciation, an annual allocation that depends on a number of estimates as well as a choice among methods. The choice of depreciation method, in particular straight-line versus an accelerated method, leads to some interesting conceptual discussions. First, although both record the same total amount of depreciation over the life of the asset, straight-line shows the same expense in each year, while the accelerated methods show higher depreciation in early years and lower depreciation in later years in comparison to straight-line. Straight-line depreciation typically is employed for assets, such as buildings, whose revenue-generating ability does not change from year to year; thus revenues and expenses are best matched from year to year. On the other hand, the conceptual argument for accelerated depreciation is that some assets, such as machines for which units of production estimates are difficult to make, are generally capable of producing higher revenues in the earlier years and can bear the higher corresponding depreciation expense - again a kind of matching argument. In later years, higher repairs expense plus lower depreciation result in a fair expense recognition measurement. 
The conceptual issues associated with disposal of fixed assets relate primarily to gain/loss recognition. If an asset's book value (original cost less accumulated depreciation) is less than the cash received, when the accountant removes that book value from the books upon disposal, a gain must be recognized. This might seem like a good thing, because it will increase net income in the year of disposal. But what it really indicates is that the rate of depreciation recognized (expense recognition) in the preceding years of the asset's use was too high; thus depreciation expense has been overstated (and income) understated for all previous years. It all "offsets," but income has been misstated in every year, taking us far from our goal of reflecting economic reality. Still, the estimates (for both useful life and salvage value) make small losses and gains on sale inevitable. Using estimates, choices, or judgments to manipulate or smooth income, however, can become excessive, and the next section offers some of the times when companies have elected to stray from the path to the mountaintop, resulting in scandals that made the news.

\section{FIXED ASSETS IN THE NEWS AND LITERATURE}

When the FASB permits choices in accounting procedures, when accountants must make estimates, or when judgment is involved, one can rest assured that, at some point, some companies will elect to skirt the trailhead and head off in some direction other than that which would take it to the mountaintop. Such is the case with property, plant, and equipment. Accountants may elect depreciation methods, must estimate useful lives and salvage values, and must determine how to handle post-acquisition expenditures on a regular basis. When times are tough (income is coming in below expectations), the temptation exists to use these gray areas to buoy up or smooth income. Often this can lead to beyond-GAAP accounting, and some of the more interesting news stories follow.

Capitalization versus expensing constitutes the primary issue for the 2002 WorldCom, Inc. scandal. That summer the company confessed that nearly $\$ 4$ billion in expenditures had been capitalized (debited to an asset account) rather than expensed (appropriate, because no future expected benefits were expected to accrue from this spending). Internal auditors working for the company uncovered the fraud, and the subsequent investigation revealed the fact that the CFO of the company had instructed accountants to force the financial statements to reflect targeted earnings figures. One of the largest restatements of income in history precipitated the ultimate collapse of the corporation whose total market value once stood at about $\$ 120$ billion. [For a full story, see www.accountancyage.com/accountancyage/specials /2039195/worldcom-trial.]

Another PP\&E-related area subject to earnings manipulation and fraud includes the write-down of assets when their future cash flow generating potential has become impaired. This "big bath accounting" is often used in cases where a company's earnings are already far below expectations, and the idea is to take the hit all at once, recording allegedly non-repeatable losses with the intent of then buoying up future years' earnings through the resulting lower annual depreciation expense. As a Business Week article states it: “...The aim of many of today's giant write-offs is to front-load expenses. Charge off three years of expenses all at once, and by definition future earnings will be better" [1998, p. 135, as cited in Spiceland et al., 2007, p. 482]. Other examples include American Airlines' write-down of $\$ 685$ million in the book value of certain aircraft in 2001 as well as AT\&T's $\$ 11$ billion asset impairment charge in 2004 [also cited in Spiceland et al., 2007]. While it is difficult to prove such accounting is fraudulent, a number of studies have shown that, in hindsight, reflecting economic reality has not been at the forefront of such activities [See Beneish 1999, p. 28; Beneish and Vargus, 2002, p. 786; Rosner 2003; Schipper, 2003; and Marquardt and Wiedman, 2004].

A number of articles have addressed the use of depreciation in managers' attempts to smooth income over time. Lane and Willett [1997, p. 192] contend that depreciation "....need not be arbitrary but may be engineered to improve the statistical properties of earnings as an estimator of long-run cash flow," while Hillier and McCrae find little difference between straight-line and reducing balance depreciation in smoothing income; they state that estimated useful lives and salvage estimates are much more important [1998, pp. 86-87]. Plummer and Mest investigate which components firms use to manage bottom-line reported earnings and find no evidence that depreciation expense is widely used to achieve this goal [2001, p. 320]. For an excellent summary of the research on predicting future cash flows (and the role of accruals in that process), see Barth et al. [2001]. 


\section{THIS SERIES CONTINUES}

This article provided the fourth installment in a series of brief articles connecting the theoretical constructs of the conceptual framework to the major accounting elements. It offered some conceptual insights into property, plant, and equipment, looked at some headline stories, and listed a few approachable articles addressing issues related to fixed assets. The next installment in the series will look at the prime concerns accountants face as they measure and report long-lived intangible assets such as patents, trademarks, and copyrights.

\section{REFERENCES}

1. Barth, Mary E.; Donald P. Cram, and Karen K. Nelson. 2001. Accruals and the Prediction of Future Cash Flows. The Accounting Review. Vol. 76, No. 1: 27-58.

2. Beneish, Messod D. 1999. The Detection of Earnings Manipulation. Financial Analysts Journal. Vol. 55, Issue 5: 24-36.

3. Beneish, Messod D. and Mark E. Vargus. 2002. Insider Trading, Earnings Quality, and Accrual Mispricing. The Accounting Review. Vol. 77, No. 4: 755-791.

4. Earnings Hocus-Pocus: How Companies Come Up with the Numbers They Want. 1998. Business Week. October 5, p. 135.

5. Financial Accounting Standards Board. 1980. Qualitative Characteristics of Accounting Information. Statement of Financial Accounting Concepts No. 2. Stamford, Conn.

6. Hillier, John and Michael McCrae. 1998. The Earnings Smoothing Potential of Systematic Depreciation. ABACUS. Vol. 34, No. 1: 75-91.

7. Lane, John and Roger Willett. 1997. Depreciation Need Not Be Arbitrary. Accounting and Business Research. Vol. 27, No. 3: 179-194.

8. Laux, Judith A. 2007. Accounting Issues: An Essay Series Part I-Introduction to Accounting Theory and 'Cash.' Journal of College Teaching \& Learning, Vol. 4, No. 1: 61-65.

9. 2007. Accounting Issues: An Essay Series Part II-Accounts Receivable. Journal of College Teaching \& Learning, Vol. 4, No. 4: 1-6.

10. 2007. Accounting Issues: An Essay Series Part III-Inventory. Journal of College Teaching \& $\overline{\text { Learning, third quarter. }}$

11. Marquardt, Carol A. and Christine I. Wiedman. 2004. How Are Earnings Managed? An Examination of Specific Accruals. Contemporary Accounting Research. Vol. 21, No. 2: 461-491.

12. Plummer, Elizabeth and David P. Mest. 2001. Evidence on the Management of Earnings Components. Journal of Accounting, Auditing \& Finance. Vol. 6, Issue 4: 301-323.

13. Rosner, Rebecca L. 2003. Earnings Management in Failing Firms. Contemporary Accounting Research. Vol. 20, Issue 2: 361-408.

14. Schipper, K. and L. Vincent. 2003. Earnings Quality. Accounting Horizons, 17 (Supplement): 97-110.

15. Spiceland, J. David; James F. Sepe; Lawrence A. Tomassini. 2007. Intermediate Accounting, $4^{\text {th }}$ ed. McGraw-Hill.

16. WorldCom Trial-Accountancy Age. www.accountancyage.com/accountancyage/specials/2039195/ worldcom-trial. 